Saudi Journal of Medicine

Abbreviated Key Title: Saudi J Med ISSN 2518-3389 (Print) |ISSN 2518-3397 (Online) Scholars Middle East Publishers, Dubai, United Arab Emirates Journal homepage: https://saudijournals.com/sjm

Original Research Article

\title{
Pathological Complications of LRTI
}

\author{
Dr. Krishna Prasad R ${ }^{1}$, Dr. Shreesha Khandige ${ }^{2 *}$
}

${ }^{1}$ Associate Professor, Department of TB and Chest (Respiratory Medicine), Kanachur Institute of Medical Sciences, Deralakatte, Mangalore, India ${ }^{2}$ Professor and HOD, Department of Pathology, Kanachur Institute of Medical Sciences, Deralakatte, Mangalore, India

DOI: $10.36348 / \mathrm{sjm} .2020 . \mathrm{v} 05 \mathrm{i} 02.009$

| Received: 03.02.2020 | Accepted: 10.02.2020 | Published: 14.02.2020

*Corresponding author: Dr. Shreesha Khandige

\section{Abstract}

Acute respiratory infections are one of the causes of morbidity and mortality in our country. The present study was undertaken to study the complications of lower respiratory tract infection.

Keywords: LRTI, Morbidity, Mortality, Children below 5 years.

Copyright @ 2020: This is an open-access article distributed under the terms of the Creative Commons Attribution license which permits unrestricted use, distribution, and reproduction in any medium for non-commercial use (NonCommercial, or CC-BY-NC) provided the original author and source are credited.

\section{INTRODUCTION}

There is no hard and fast definition of LRTI that is universally agreed upon. Essentially, it is inflammation of the airways/pulmonary tissue, due to viral or bacterial infection, below the level of the larynx. Remember that gastro-oesophageal reflux may cause a chemical pneumonitis. Moke and chemical inhalation may also cause pulmonary inflammation.

\section{Viral-infections [2]}

About $45 \%$ of hospitalised with pneumonia have a viral aetiology [3].

\section{This includes}

- Influenza A.

- Respiratory syncytial virus (RSV)[4].

- Human metapneumovirus (hMPV)[2].

- Varicella-zoster virus (VZV) - chickenpox.

\section{Bacterial-infections}

These constitute about $60 \%$ of hospitalised pneumonia cases [3]:

- Streptococcus pneumoniae (the majority of bacterial pneumonias).

- H. influenzae.

- Staphylococcus aureus.

- Klebsiella pneumoniae.

- Enterobacteria - eg, Escherichia coli.

- Anaerobes.

\section{Atypical organisms}

- Mycoplasma pneumoniae (14\% of all cases of hospitalised pneumonia [3].
- Legionella-pneumophila

Chlamydophila pneumoniae (9\% of hospitalised with pneumonia [3]).

- Coxiella burnetii.

Lower respiratory infections are among the commonest causes of morbidity and mortality, especially in in a country like ours. The vaccine is a must to fight against the commonly occurring infections. But in a country like ours where the partially immunized are there is higher than of getting the infections [8]. Overcrowding and dense population also results in the increasing pattern of the same [9]. Martineau AR et studies showed that slightly more cases are associated with overcrowding, that is, $91.35 \%$ and $80.87 \%$ respectively [10]. Muhe Let al in Malaysia showed a significant association between ALRI and overcrowding. The spread of infection via respiratory droplets may be aggravated by overcrowding and also densely populated urban and semi-urban areas. Malnutrition also plays an important role in infections as suggested by many studies. A proposed pathophysiologic mechanism is that neutrophils have reduced the ability to kill Staphylococcus aureus due to reduced activity of myeloperoxidase, and the T-cells in circulation are reduced in number and they have defective DNA synthesis due to the attenuated activity of ribonucleotide reductase [11].

The present study was undertaken to study the various risk factors, clinical presentations and outcome of lower respiratory tract infections. 


\section{AIMS AND OBJECTIVES}

To study the pathological complicatons in LRTI

\section{MATERIALS AND METHODS}

This study was done in the Department of Respiratory Medicine, Kanachur I statute of Medical Sciences. This study was done from August 2017 to July 2018. The study was done in 60 cases that were delivered and a reference had been sought from the Department of Pediatrics.

\section{Inclusion Criteria}

Clinically confirmed cases

\section{Exclusion Criteria}

Steroid and other immune-suppressant therapy

\section{RESULTS}

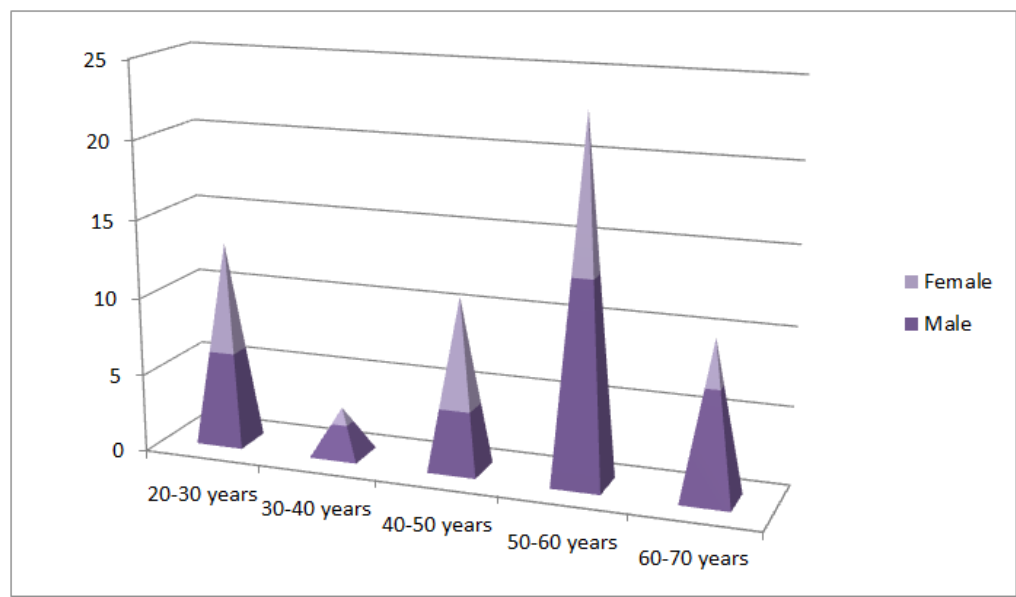

Graph-1: Age and Sex Distribution

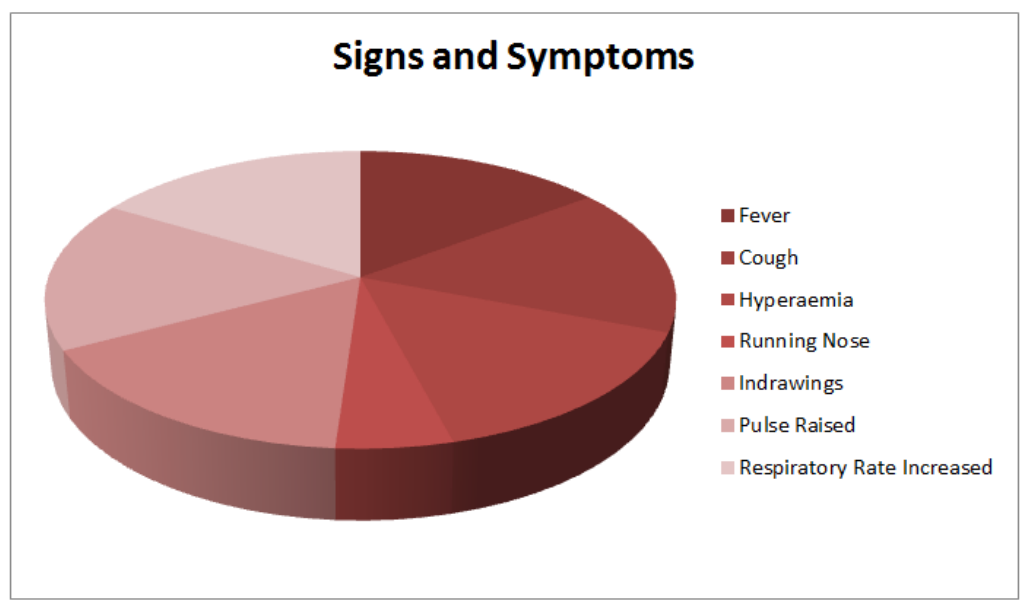

Graph-2: Signs and Symptoms

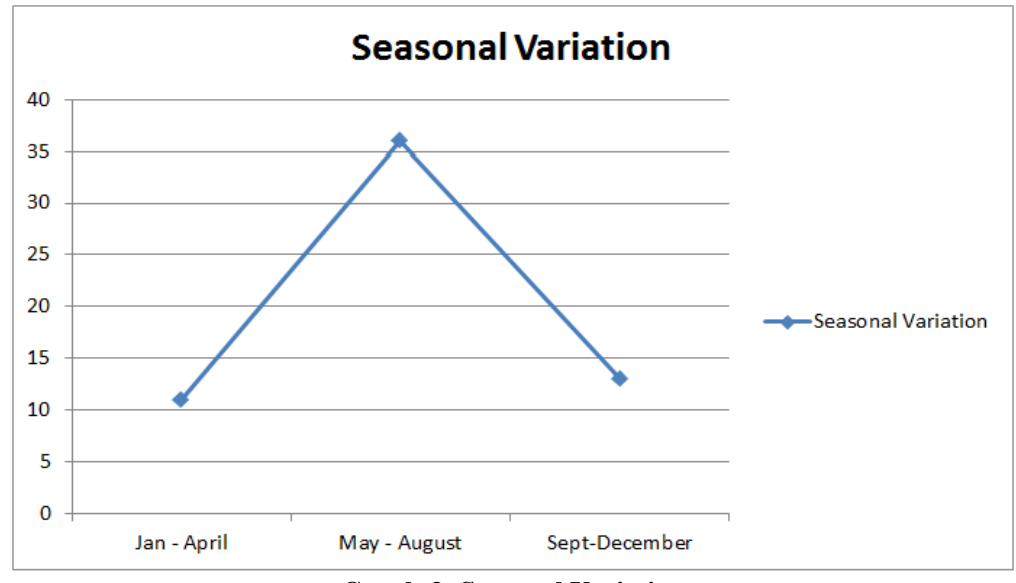

Graph-3: Seasonal Variation 


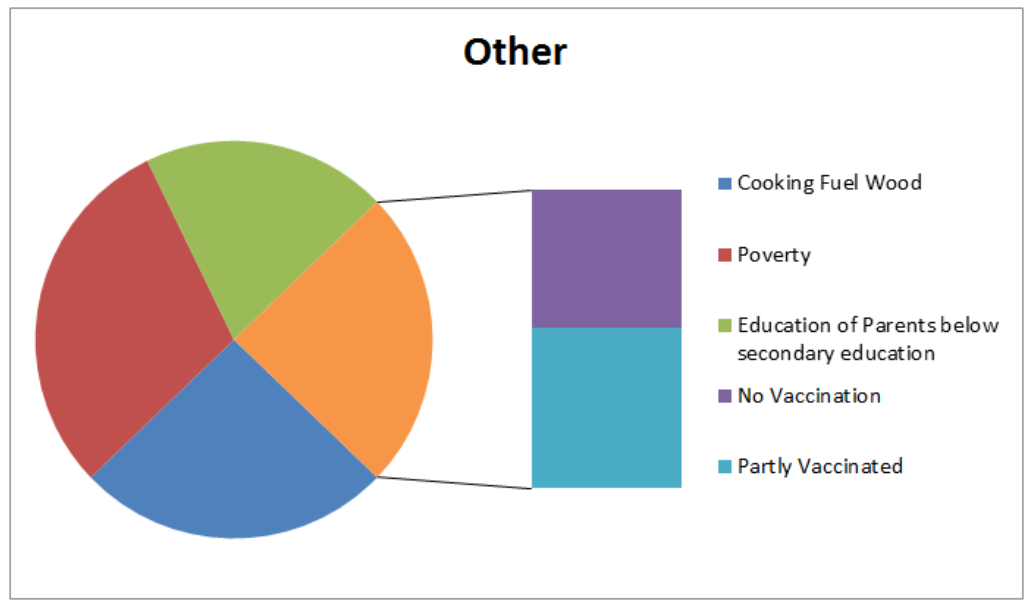

Graph-4: Other Demographic factors

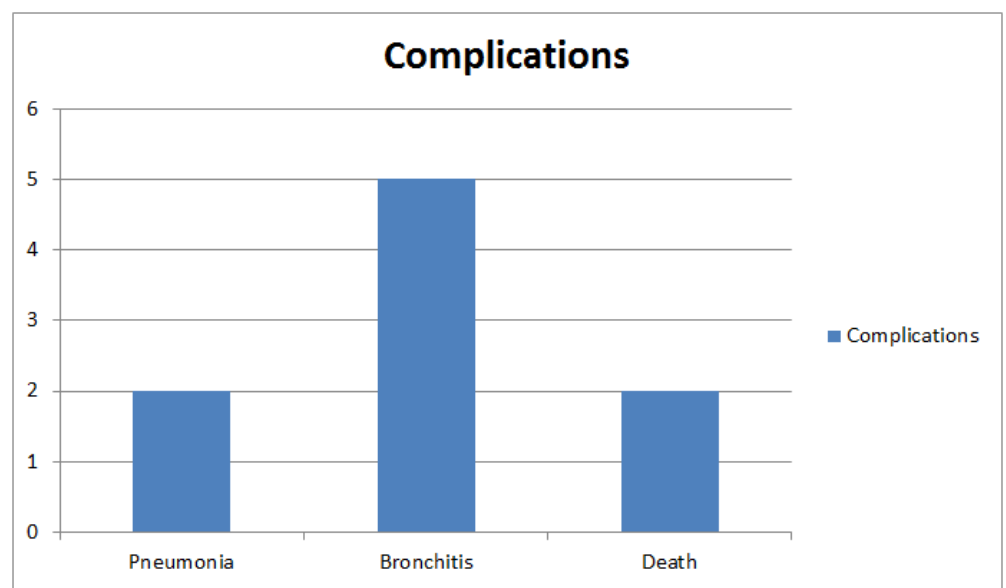

Graph-3: Complications

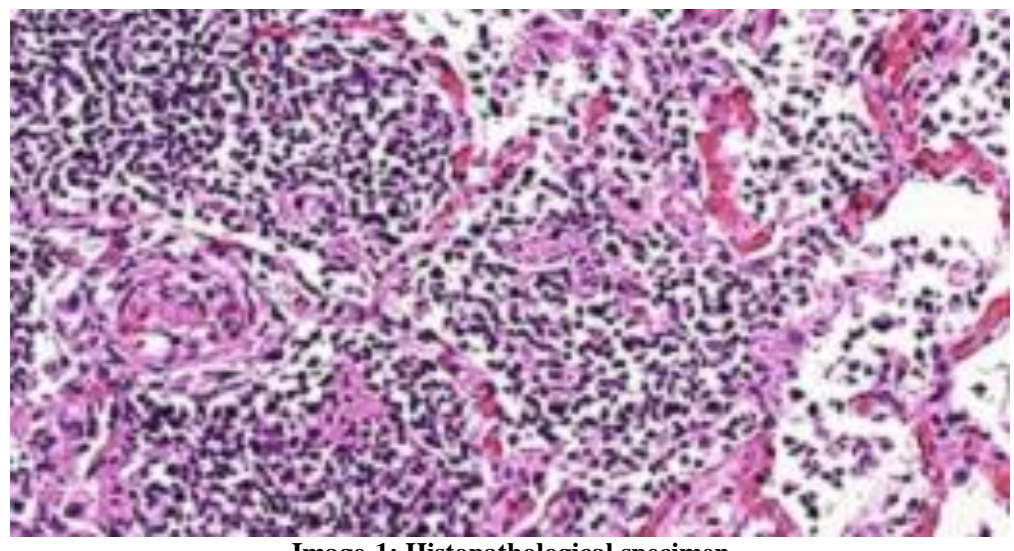

Image-1: Histopathological specimen

\section{DISCUSSION}

Overall epidemiological data are poor because accurate diagnosis is limited by diagnostic methodology. The estimated incidence of LRTI is 30 per 1,000 per year in the UK. UK data seen at hospital with pneumonia (clinical findings and CXR) in 20012002 found overall incidence rates of 14.4 per 10,000 per annum and 33.8 for those aged $\leq 5$ years[1]. Males were more often affected than females. Haemophilus influenzae infection is now quite rare amongst UK based citizens because of immunisation. Acute respiratory infections are one of the causes of morbidity and mortality in our country especially in the extremes of age. Around 100 million new episodes each year, of which India ac-counts for a bulk of 33 percent [1]. The mortality is estimated around 1.9 million per year, out of which India accounts for aroundone ourth roughly [2]. The WHO Programme for ARI Control guidelines define Pneumonia as cough in the presence of tachypnoea (respirato-ry rate $>30 / \mathrm{min}$ in adults and Severe and Very Severe Pneumonia as the presence of chest in-drawing and central cyanosis, lethargy, convulsions and refusal of feeds of respectively[3]. Tachypnoea and lower chest indrawing, when applied 
by health workers and physicians as a diagnostic tool, had the sensitivity of $70 \%$ and $81 \%$ respectively [4]. ARI is responsible for about $30-50$ percent of visits to health facilities and for about 20-40 percent of admissions to hospitals [5]. In addition, immunocompromised individuals of all ages are at increased risk[6]. Likewise, Haemophilus influenza type $b$ (Hib) bacteria is estimated to cause 3 million cases of severe pneumonia and meningitis, and approximately 386,000 deaths per year [7].

\section{CONCLUSION}

The complications should be dealt with more serious and prompt actions otherwise it could be more dangerous than expected.

\section{REFERENCES}

1. Chantry, C.J., Howard, C.R., Auinger, P. (2018). Full breastfeeding duration and associated decrease in Dhivyanarayani M. Int J Contemp Pediatr, Jul; 5(4):1322-1326

2. Cowgill, K.D., Ndiritu, M., Nyiro, J., Slack, M.P., Chiphatsi, S., Ismail, A. (2006). Effectiveness of Haemophilus influenzae type $b$ conjugate vaccine introduction into routine childhood immunization in Kenya. JAMA, 296:671-8.

3. Ganong, W.F. (2005). Gas transport between the lungs and tahe tissue. In: Ganong WF. Review of medical physiology. 22nd ed. New York. McGraw Hill, 666-9.
4. Ganz, T. (2003). Defensins: antimicrobial peptides of innate immunity. Nat Rev Immunol, 3(9):710-20.

5. Guyton and Hall Textbook of medical physiology. 11th ed. (2006). Philadelphia. Saunders Elsevier, 507- 8 .

6. Hawkes, J.S., Neumann, M.A., Gibson, R.A.(1999). The effect of breastfeeding on lymphocyte subpopulations in healthy term infants at 6 months of age. Pediatr Res, 45:648-51.

7. Jain, L., Vidyasagar, D., Xanthou, M., Ghai, V., Shimada, S., Blend, M. (1989). In vivo distribution of human milk leukocytes after ingestion by newborn baboons. Arch Dis Child, 64:930-3.

8. Janssen, R., Bont, L., Siezen, C.L. (2007). Genetic susceptibility to respiratory syncytial virus bronchiolitis is predominantly associated with innate immune genes. J Infect Dis, 196(6):826-34.

9. Letterio, J.J., Geiser, A.G., Kulkarni, A.B., Roche, N.S., Sporn, M.B., Roberts, A.B. (1994). Maternal rescue of transforming growth-beta 1 null mice. Science, 264:1936-8.

10. Martineau, A.R., Wilkinson, R.J., Wilkinson, K.A., Newton, S.M., Kampmann, B., Hall, B.M. (2007). A single dose of vitamin D enhances immunity to mycobacteria. Am J Respir Crit Care Med, 176(2):208-13.

11. Muhe, L., Lulseged, S., Mason, K.E., Simoes, E.A.(1997). Casecontrol study of the role of nutritional rickets in the risk of developing pneumonia in Ethiopian children. Lancet, 349(9068):1801-4. 